\title{
Oocyte depletion in XO mice and their XX sibs from 12 to 200 days post partum
}

\author{
P. S. Burgoyne* and T. G. Baker $\dagger$ \\ Department of Obstetrics \& Gynaecology, University of Edinburgh, 37 Chalmers Street, \\ Edinburgh EH3 $9 E W, U . K$.
}

\begin{abstract}
Summary. The total number of oocytes (healthy and atretic) in XO and XX mice at ages ranging from 12 to 200 days after birth was determined using a quantitative histological technique. For each oocyte the stage of the enveloping follicle was recorded. The results demonstrated that throughout the period studied XO mice had approximately half the number of oocytes found in XX mice. No increase in the incidence of atresia was detected in XO ovaries. In XO mice at 12 days of age the establishment of the population of growing follicles was clearly retarded.
\end{abstract}

\section{Introduction}

Ohno (1969) has presented evidence that the genetic content of the $\mathrm{X}$ chromosome has been conserved during the evolution of mammals. One consequence of such genetic conservation should be that $\mathrm{X}$ chromosome monosomy will be associated with the same primary defects in all mammalian species. In apparent contradiction to this was the discovery that adult XO mice have histologically normal ovaries and are fertile (Welshons \& Russell, 1959; Cattanach, 1962) whereas XO (Turner's syndrome) women are almost always infertile with the ovaries represented by connective tissue streaks (Simpson, 1976). This seemingly major disparity between the XO phenotype of the two species was reduced when Singh \& Carr (1966) reported that oocytes are found in the ovaries of XO human abortuses (germ cell loss occurring in the second half of pregnancy), and Lyon \& Hawker (1973) showed that XO mice become sterile earlier than their XX sibs. Lyon \& Hawker (1973) suggested that the premature sterility of XO mice was due to the exhaustion of a reduced oocyte pool. The present study investigated this suggestion and the extent and timing of oocyte loss.

\section{Materials and Methods}

The material consisted of serial sections of 40 ovaries from XO mice and 40 ovaries from XX mice. The mice comprised $4 \mathrm{sib}$ pairs at each of the ages 12, 25, 50, 100 and 200 days. The mice were derived as follows. Firstly, stud males carrying the $\mathrm{X}$ inversion $\mathrm{In}(\mathrm{X}) 1 \mathrm{H}$ (Evans \& Phillips, 1975) were mated to outbred Schofield albino females (S. Schofield \& Co., Delph, nr Oldham, Lancs). The heterozygous $\operatorname{In}(\mathrm{X}) / \mathrm{X}$ female offspring were subsequently mated to Schofield albino males to provide litters in which about $25 \%$ of the females are XO (Phillips, Hawker \& Moseley,

\footnotetext{
* Present address: MRC Mammalian Development Unit, Wolfson House, 4 Stephenson Way, London NW1 2HE, U.K. U.K.

† Present address: Department of Medical Sciences, University of Bradford, Bradford, West Yorkshire BD7 IDP,
} 
1973). Males were culled from the litters at birth. The females of each litter were kept caged together until they were weighed, killed and karyotyped (using bone marrow cells). One XO (if present) and one XX female were randomly selected from within each litter; the ovaries were fixed in aqueous Bouin, processed for histology, serially sectioned at $6 \mu \mathrm{m}$, and stained with haematoxylin and eosin. All the sectioned material was coded and randomized before counting The procedures for counting oocytes, classifying follicles and assessing atresia were essentially those of Mandl \& Zuckerman (1950) and have been described by Baker, Challoner \& Burgoyne (1980). For the present work a section interval of 1 in 10 was used.

Ovaries were also obtained and processed from some XO and XX mice aged 400 days to provide material for a qualitative assessment of longer term changes in the XO ovary.

Table 1. Total numbers of oocytes, together with their distribution between pool (stage I) and growing (stages II-VI) follicles, for XO and XX mice at 12, 25, 50, 100 and 200 days after birth

\begin{tabular}{|c|c|c|c|c|c|c|c|}
\hline \multirow[b]{2}{*}{$\begin{array}{c}\text { Age } \\
\text { (days) }\end{array}$} & \multirow[b]{2}{*}{$\begin{array}{l}\text { Sib } \\
\text { pair }\end{array}$} & \multicolumn{3}{|c|}{$\mathrm{XX}$ mice } & \multicolumn{3}{|c|}{$\mathrm{XO}$ mice } \\
\hline & & $\begin{array}{l}\text { Pool } \\
\text { (I) }\end{array}$ & $\begin{array}{l}\text { Growing } \\
\text { (II-VI) }\end{array}$ & Total & $\begin{array}{l}\text { Pool } \\
\text { (I) }\end{array}$ & $\begin{array}{l}\text { Growing } \\
\text { (II-VI) }\end{array}$ & Total \\
\hline 12 & $\begin{array}{l}1 \\
2 \\
3 \\
4\end{array}$ & $\begin{array}{l}23040 \\
19460 \\
20550 \\
15740\end{array}$ & $\begin{array}{l}2500 \\
1530 \\
2170 \\
2450\end{array}$ & $\begin{array}{l}25540 \\
20990 \\
22720 \\
18190\end{array}$ & $\begin{array}{r}15150 \\
6170 \\
9850 \\
9050\end{array}$ & $\begin{array}{l}2210 \\
1710 \\
1780 \\
2070\end{array}$ & $\begin{array}{r}17360 \\
7880 \\
11630 \\
11120\end{array}$ \\
\hline $\begin{array}{l}\text { Mean } \\
\pm \text { s.e.m. }\end{array}$ & & $\begin{array}{l}19698 \\
\pm 1517\end{array}$ & $\begin{array}{r}2162 \\
\pm 223\end{array}$ & $\begin{array}{l}21860 \\
\pm 1541\end{array}$ & $\begin{array}{l}10055 \\
\pm 1873\end{array}$ & $\begin{array}{r}1942 \\
\pm 118\end{array}$ & $\begin{array}{l}11998 \\
\pm 1971\end{array}$ \\
\hline 25 & $\begin{array}{l}1 \\
2 \\
3 \\
4\end{array}$ & $\begin{array}{r}14950 \\
10240 \\
15410 \\
9110\end{array}$ & $\begin{array}{l}2500 \\
1710 \\
2620 \\
1940\end{array}$ & $\begin{array}{l}17450 \\
11950 \\
18030 \\
11050\end{array}$ & $\begin{array}{r}12960 \\
8290 \\
8000 \\
9880\end{array}$ & $\begin{array}{l}1580 \\
1410 \\
1720 \\
2120\end{array}$ & $\begin{array}{r}14540 \\
9700 \\
9720 \\
12000\end{array}$ \\
\hline $\begin{array}{l}\text { Mean } \\
\pm \text { s.e.m. }\end{array}$ & & $\begin{array}{l}12428 \\
\pm 1608\end{array}$ & $\begin{array}{r}2192 \\
\pm 219\end{array}$ & $\begin{array}{r}14620 \\
\pm 1814\end{array}$ & $\begin{array}{r}9782 \\
\pm 1137\end{array}$ & $\begin{array}{r}1708 \\
\pm 151\end{array}$ & $\begin{array}{l}11490 \\
\pm 1151\end{array}$ \\
\hline 50 & $\begin{array}{l}1 \\
2 \\
3 \\
4\end{array}$ & $\begin{array}{r}8060 \\
9080 \\
7860 \\
15200\end{array}$ & $\begin{array}{l}2770 \\
2520 \\
3150 \\
2660\end{array}$ & $\begin{array}{l}10830 \\
11600 \\
11010 \\
17860\end{array}$ & $\begin{array}{l}6120 \\
2040 \\
3050 \\
3050\end{array}$ & $\begin{array}{l}2500 \\
1540 \\
3000 \\
1510\end{array}$ & $\begin{array}{l}8620 \\
3580 \\
6050 \\
4560\end{array}$ \\
\hline $\begin{array}{l}\text { Mean } \\
\pm \text { s.e.m. }\end{array}$ & & $\begin{array}{l}10050 \\
\pm 1737\end{array}$ & $\begin{array}{r}2775 \\
\pm 135\end{array}$ & $\begin{array}{r}12825 \\
\pm 1686\end{array}$ & $\begin{array}{r}3565 \\
\pm 884\end{array}$ & $\begin{array}{r}2138 \\
+368\end{array}$ & $\begin{array}{r}5702 \\
\pm 1097\end{array}$ \\
\hline 100 & $\begin{array}{l}1 \\
2 \\
3 \\
4\end{array}$ & $\begin{array}{r}12200 \\
9260 \\
13760 \\
6490\end{array}$ & $\begin{array}{l}2700 \\
3120 \\
2690 \\
1800\end{array}$ & $\begin{array}{r}14900 \\
12380 \\
16450 \\
8290\end{array}$ & $\begin{array}{l}4720 \\
2210 \\
3380 \\
4310\end{array}$ & $\begin{array}{l}1860 \\
2090 \\
1980 \\
2250\end{array}$ & $\begin{array}{l}6580 \\
4300 \\
5360 \\
6560\end{array}$ \\
\hline $\begin{array}{l}\text { Mean } \\
\pm \text { s.e.m. }\end{array}$ & & $\begin{array}{l}10428 \\
\pm 1610\end{array}$ & $\begin{array}{r}2578 \\
\pm 278\end{array}$ & $\begin{array}{l}13005 \\
\pm 1781\end{array}$ & $\begin{array}{r}3655 \\
\pm 557\end{array}$ & $\begin{array}{r}2045 \\
\pm 83\end{array}$ & $\begin{array}{r}5700 \\
\pm 547\end{array}$ \\
\hline 200 & $\begin{array}{l}1 \\
2 \\
3 \\
4\end{array}$ & $\begin{array}{l}2170 \\
2970 \\
3280 \\
6270\end{array}$ & $\begin{array}{l}1530 \\
1280 \\
2000 \\
1760\end{array}$ & $\begin{array}{l}3700 \\
4250 \\
5280 \\
8030\end{array}$ & $\begin{array}{r}1^{*} \\
2670 \\
990 \\
1430\end{array}$ & $\begin{array}{r}3^{*} \\
850 \\
920 \\
1060\end{array}$ & $\begin{array}{c}4^{*} \\
3520 \\
1910 \\
2490\end{array}$ \\
\hline $\begin{array}{l}\text { Mean } \\
\pm \text { s.e.m. }\end{array}$ & & $\begin{array}{r}3672 \\
\pm 897\end{array}$ & $\begin{array}{r}1642 \\
\pm 154\end{array}$ & $\begin{array}{r}5315 \\
\pm 962\end{array}$ & $\begin{array}{r}1272 \\
\pm 553\end{array}$ & $\begin{array}{r}708 \\
+229\end{array}$ & $\begin{array}{r}1981 \\
+738\end{array}$ \\
\hline
\end{tabular}




\section{Results}

Our observations on ovarian histology fully accord with those of Lyon \& Hawker (1973), the ovaries of XO mice being abnormal only in that they have the appearance of older XX ovaries.

The data obtained on oocyte numbers are summarized in Table 1. With the exception of sib pair 4 at 25 days, all ovaries from XO mice had fewer oocytes than did those from their XX sibs.

The large differences between females of the same genotype within an age group preclude any accurate estimates of mean oocyte numbers at specific ages. Examination of XO-XX sib pair differences revealed similar variability so that mean differences are also poorly estimated. However, it has been shown previously (Jones \& Krohn, 1961) that the oocyte depletion curve gives a good fit to a straight line if oocyte numbers are expressed as logarithms. Accordingly the present $\mathrm{XX}$ and $\mathrm{XO}$ data were log-transformed and regression lines fitted (Text-fig. 1). The fit to a straight line was satisfactory for both genotypes $(\mathrm{XX}, r=0.85 ; \mathrm{XO}, r=0.84)$. Comparison of the regression lines (Snedecor \& Cochran, 1967) revealed that (i) the two slopes did not differ, and (ii) the $\mathrm{XX}$ regression line was significantly higher than the $\mathrm{XO}$ regression line $(P<0.005)$. Thus the analysis demonstrates that $\mathrm{XO}$ mice have fewer oocytes than XX mice, but during the period studied the rate of oocyte loss is the same as for XX mice on a proportional basis. The latter observation is supported by our finding that the rates of atresia were the same for the two genotypes (Table 2). From the difference in the heights of the regression lines it can be calculated that the XO mice had only $53 \%$ of the oocyte population of their XX sibs. However, the extent of the reduction varied widely from one XO mouse to another (Table 3).

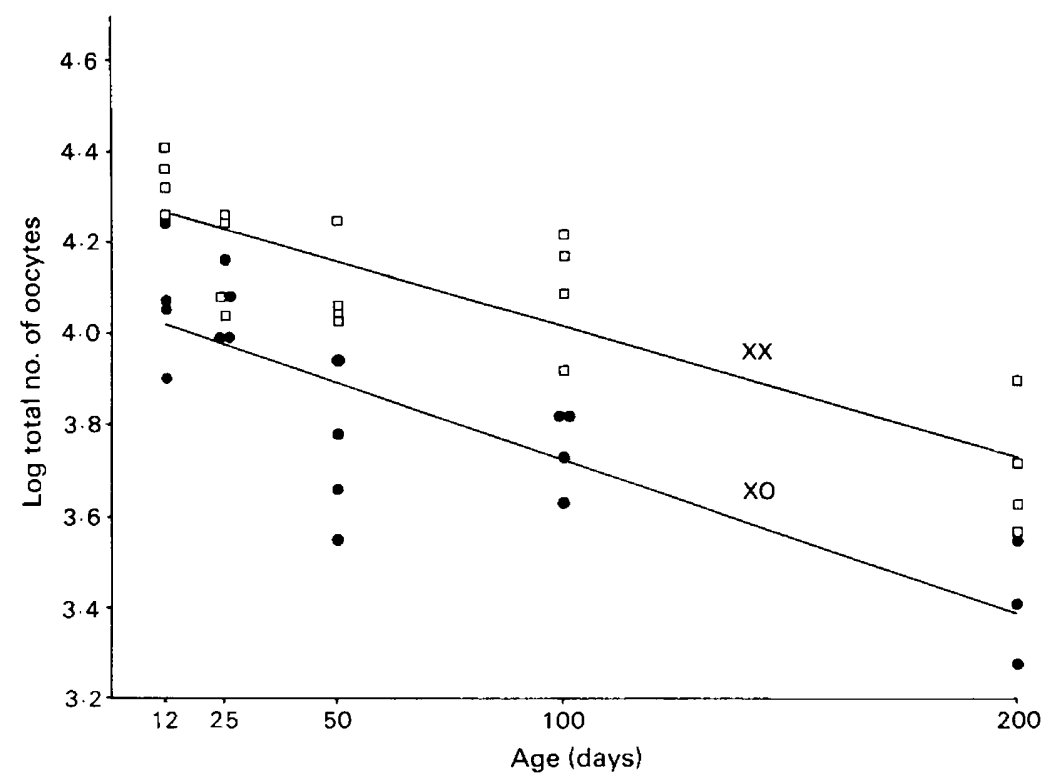

Text-fig. 1. The relationship between age and $\log$ total numbers of oocytes for XO (0) and XX ( $\square$ ) mice. One point $(0.6,200$ days $)$ has been excluded because it was an outlier $(P<0.01$; see p. 157 Snedecor \& Cochran, 1967). The regression equations were (a) XO, $y=-0.00340 x+$ 4.07 , and (b) XX, $y=-0.00286 x+4.30$.

Since oocytes were classified with respect to the stage of development of the enveloping follicles, the relative proportions of the different follicular stages could be compared for the two genotypes. The data on pool sizes (stage I follicles) and on the numbers of growing follicles (stages II-VI) were unremarkable in the light of the observations on total oocyte numbers, both being reduced in $\mathrm{XO}$ mice (Table 1). The reduction was proportionately greater for the pool than 
Table 2. The mean percentage atresia ( \pm s.e.m.) for pool (stage $I)$ and growing (stages II-VI) follicles in $\mathrm{XO}$ and $\mathrm{XX}$ mice

\begin{tabular}{|c|c|c|c|c|}
\hline \multirow{3}{*}{$\begin{array}{c}\text { Age } \\
\text { (days) }\end{array}$} & \multicolumn{4}{|c|}{ Follicular stages } \\
\hline & \multicolumn{2}{|c|}{ Pool (I) } & \multicolumn{2}{|c|}{ Growing (II-VI) } \\
\hline & $\mathrm{XX}$ & Xo & $x x$ & Xo \\
\hline 12 & $43.3 \pm 0.5$ & $42.8 \pm 0.8$ & $22 \cdot 6 \pm 2 \cdot 8$ & $23 \cdot 2 \pm 1 \cdot 8$ \\
\hline 25 & $39.0 \pm 0.5$ & $40.4 \pm 1.3$ & $26.0 \pm 1.6$ & $28.6 \pm 4.6$ \\
\hline 50 & $38.8 \pm 0.6$ & $38.6 \pm 1.0$ & $30.5 \pm 1.3$ & $36 \cdot 3 \pm 3 \cdot 8$ \\
\hline 100 & $40 \cdot 0 \pm 1 \cdot 1$ & $40.4 \pm 1.4$ & $30 \cdot 6 \pm 2 \cdot 7$ & $30.2 \pm 1.6$ \\
\hline 200 & $38.4 \pm 1.0$ & $33 \cdot 6 \pm 3.5$ & $33 \cdot 3 \pm 2 \cdot 0$ & $27.6 \pm 1.9$ \\
\hline
\end{tabular}

Table 3. The number of oocytes in individual XO mice as a percentage of the mean number of oocytes in XX mice of the same age

\begin{tabular}{|c|c|c|c|c|}
\hline \multirow{2}{*}{$\begin{array}{c}\text { Age } \\
\text { (days) }\end{array}$} & \multicolumn{3}{|c|}{ No. of oocytes (XO) } & \multirow{2}{*}{$100(\%)$} \\
\hline & Mean $n$ & of ooc & $(\mathrm{XX})$ & \\
\hline 12 & 79.4 & $36 \cdot 0$ & $53 \cdot 2$ & 50.9 \\
\hline 25 & 99 & & & 82 \\
\hline 50 & 67.2 & 27 & 47 & 35 \\
\hline 100 & 50.6 & $33 \cdot 1$ & 41.2 & 50.4 \\
\hline 200 & $(0 \cdot 1)^{*}$ & $66 \cdot 2$ & 35.9 & $46 \cdot 8$ \\
\hline
\end{tabular}

* This mouse should perhaps be excluded on statistical grounds. See Text-fig. 1.

for growing follicles. Comparisons (using the original counts) of the distribution of oocytes among the follicular stages II-VI revealed some important differences between $\mathrm{XO}$ and $\mathrm{XX}$ mice. At 12 days the $\chi^{2}$ value was highly significant $(P<0.0005)$, due to major differences in the proportions of follicles at stages II, IV and V + VI (pooled because of small numbers). These differences represent a retardation of follicular development in XO mice (Table 4). The $\chi^{2}$ values were also significant $(0.001<P<0.005)$ for the 25 - and 100-day groups, and in both this was due to an increased proportion of stage $\mathrm{V}$ follicles in the $\mathrm{XO}$ individuals (Table 4).

Table 4. The mean number of oocytes in follicular classes II-VI in $\mathrm{XO}$ and $\mathrm{XX}$ mice aged 12-200 days

\begin{tabular}{ccrrrrr}
\hline \multirow{2}{*}{$\begin{array}{c}\text { Age } \\
\text { (days) }\end{array}$} & Genotype & II & III & IV & \multicolumn{1}{c}{ V } & VI \\
\cline { 3 - 7 } 12 & XO & 1330.0 & 477.5 & 117.5 & 17.5 & 0.0 \\
& XX & 1160.0 & 522.5 & 357.5 & 107.5 & 1.5 \\
25 & XO & 927.5 & 325.0 & 125.0 & 277.5 & 52.5 \\
& XX & 1310.0 & 425.0 & 182.5 & 205.0 & 72.5 \\
50 & XO & 1125.0 & 430.0 & 252.5 & 245.0 & 85.0 \\
& XX & 1607.5 & 460.0 & 305.0 & 315.0 & 87.5 \\
100 & XO & 1230.0 & 357.5 & 152.5 & 207.5 & 97.5 \\
& XX & 1677.5 & 385.0 & 225.0 & 150.0 & 140.0 \\
200 & XO & 430.0 & 120.0 & 35.0 & 77.5 & 47.5 \\
& XX & 1132.5 & 205.0 & 107.5 & 127.5 & 70.0 \\
\hline
\end{tabular}




\section{Discussion}

The results obtained in the present study demonstrate that the oocyte population is markedly reduced (approximately halved) in XO mice, thus confirming the suggestion made by Lyon \& Hawker (1973). This reduction has already occurred by 12 days post partum (the earliest age studied). At 12 days post partum follicular development is retarded, but in all other respects follicular relationships appear to be normal in XO mice. Thus follicular atresia is not increased in $\mathrm{XO}$ mice and oocytes are depleted at the same rate as in controls (i.e. the same constant proportion of the total is lost per unit time). Furthermore, the finding that the reduction in pool size in XO mice is not paralleled by an equivalent reduction in the number of growing follicles is in line with the compensation that occurs as pool size decreases with age in control mice. The same phenomenon is also observed following unilateral ovariectomy (Baker et al., 1980).

It is useful to compare the extent and timing of oocyte depletion in the XO mouse with what is known for the XO human. The ovaries are of normal appearance in XO human embryos, a decline in germ cell numbers occurring in the second half of pregnancy (Singh \& Carr, 1966: Carr, 1972). The extent of oocyte loss is variable, some XO infants having histologically normal ovaries while others have ovarian 'streaks' which are devoid of oocytes (Carr, Haggar \& Hart, 1968). In XO women, primary amenorrhoea is usual (97\% of cases: Simpson, 1976) but menstruation and pregnancy have been reported (King, Magenis \& Bennett, 1978).

Clearly, the reduction in oocyte numbers is much more severe in XO women than in XO mice. Nevertheless, a few XO women have functional ovaries containing oocytes. It is invariably assumed that the surviving oocytes in these cases are XX. Thus a paper describing a fertile XO woman (Nakashima \& Robinson, 1971) is followed by the editorial comment: "The theoretical explanation is simple ... Such a patient must be an example of undetected mosaicism with a normal cell line of $46, \mathrm{XX}$ in the germ cells." An alternative explanation follows from the current finding that there is considerable variation in the extent of loss (Table 3) and that those oocytes which survive until 12 days post partum are depleted at the normal rate. For the human XO variability in the extent of loss is suggested by the variable ovarian phenotype of XO infants, and if normal depletion rates occur subsequently there may occasionally be XO oocytes remaining at puberty. It is perhaps relevant that the prognosis for pregnancy outcome in XO or XO mosaic mothers is very poor, 33 out of 48 reported pregnancies ending in spontaneous abortion. stillbirth, neonatal death or congenital abnormality (King et al., 1978). This poor prognosis is consistent with that expected for $\mathrm{XO}$ oocytes, since any $\mathrm{XO}$ fetuses produced should almost always abort, and further pregnancy losses should accrue as a result of the poor quality of $\mathrm{XO}$ oocytes (Burgoyne \& Biggers, 1976).

The loss of XO germ cells in the human XO is said to occur throughout the period when oogonia are entering meiosis (Carr, 1972). The present data for the mouse demonstrate that the loss occurs before 12 days post partum. Furthermore, the retardation of follicular development at 12 days might indicate some delay in the meiotic process since follicular growth must await the completion of the first stages of meiosis. A qualitative assessment of $\mathrm{XO}$ and $\mathrm{XX}$ fetal mouse ovaries (A. McLaren \& P.S. Burgoyne, unpublished) has revealed that meiosis is indeed retarded in XO fetuses.

In conclusion, the present study has confirmed that oocyte loss is a consequence of $\mathrm{X}$ chromosome monosomy in the mouse, just as it is in man. We believe that studies of XO mouse ovaries from the fetal meiotic period, which are now in progress, will provide further insights into the aetiology of XO gonadal dysgenesis in man.

We thank Anne Rae and June Hardiman for dedicated and skilled technical assistance. The late Dr R. J. S. Phillips (M.R.C. Radiobiology Unit, Harwell) kindly supplied the original stock of mice carrying $\operatorname{In}(\mathrm{X}) 1 \mathrm{H}$. This work was aided by a grant from The National FoundationMarch of Dimes. 


\section{References}

Baker, T.G., Chaltoner, S. \& Burgoyne, P.S. (1980) The number of oocytes and the rate of atresia in unilaterally ovariectomized mice up to 8 months after surgery. J. Reprod. Fert. 60, 449-456.

Burgoyne, P.S. \& Biggers, J.D. (1976) The consequences of $\mathrm{X}$-dosage deficiency in the germ line: impaired development in vitro of preimplantation embryos from XO mice. Devl Biol. 5t, 109-117.

Carr, D.H. (1972) Cytogenetic aspects of induced and spontaneous abortions. Clin. Obstet. Gynec. 15, 203-219.

Carr, D.H., Haggar, R.A. \& Hart, A.G. (1968) Germ cells in the ovaries of XO female infants. Am. J. clin. Path. 49. 521-526.

Cattanach, B.M. (1962) XO mice. Genet. Res. 3, $487-490$.

Evans, E.P. \& Phillips, R.J.S. (1975) Inversion heterozygosity and the origin of XO daughters of $B p a /+$ female mice. Nature, Lond. 256, 40-41.

Jones, E.C. \& Krohn, P.L. (1961) The relationship between age, numbers of oocytes and fertility in virgin and multiparous mice. J. Endocr. 21, 469-495.

King, C.R., Magenis, E. \& Bennett, S. (1978) Pregnancy and the Turner syndrome. Obstet. Gynec. 52, 617-624.

Lyon, M.F. \& Hawker, S.G. (1973) Reproductive lifespan in irradiated and unirradiated XO mice. Genet. Res. 21, 185-194.

Mandl, A.M. \& Zuckerman, S. (1950) The numbers of normal and atretic oocytes in the mature rat. $J$. Endocr. 6, 426-435.

Nakashima, I. \& Robinson, A. (1971) Fertility in a 45,X female. Obstet. Gynec. Survey 26, 713-714.

Ohno, S. (1969) Evolution of sex chromosomes in mammals. A. Rev. Genet. 3, 495-524.

Phillips, R.J.S., Hawker, S.G. \& Moseley, H.J. (1973) Bare-patches, a new sex-linked gene in the mouse, associated with a high proportion of $\mathrm{XO}$ females. I. A preliminary report of breeding experiments. Genet. Res. 22, 91-99.

Simpson, J.L. (1976) Disorders of Sexual Differentiation-Etiology and Clinical Delineation. Academic Press, New York.

Singh, R.P. \& Carr, D.H. (1966) The anatomy and histology of XO human embryos and fetuses. Anat. Rec. 155, 369-384.

Snedecor, G.W. \& Cochran, W.G. (1967) Statistical Methods. Iowa State University Press, Ames.

Welshons, W.J. \& Russell, L.B. (1959) The Ychromosome as the bearer of male determining factors in the mouse. Proc. natn. Acad. Sci., U.S.A. $45,560-566$. 